\title{
Partisipasi Penganggaran, Asimetri Informasi, Budaya Organisasi, Komitmen Organisasi dan Senjangan Anggaran
}

\author{
I Dewa Gde Nanda Narotama ${ }^{1}$ \\ Fakultas Ekonomi dan Bisnis \\ Universitas Udayana, Indonesia
}

\author{
I Ketut Sujana ${ }^{2}$ \\ Fakultas Ekonomi dan Bisnis \\ Universitas Udayana, Indonesia
}

Surel : nandanarotama04@gmail.com

\section{ABSTRAK}

Tujuan dari penelitian ini adalah untuk menguji secara empiris pengaruh partisipasi penganggaran, asimetri informasi, budaya organisasi dan komitmen organisasi pada senjangan anggaran. Penelitian ini dilakukan di seluruh OPD di Kabupaten Tabanan. Jumlah OPD yang digunakan sebanyak 40 OPD dan jumlah sampelyang digunakan 120 orang terdiri dari Kepala OPD, Teknik analisis data yang digunakan adalah analisis regresi linier berganda. Hasil analisis ini menunjukkan bahwa partisipasi penganggaran dan asimetri informasi berpengaruh positif terhadap senjangan anggaran sedangkan budaya organisasi dan komitmen organisasi berpengaruh negatif terhadap senjangan anggaran. Hal ini menunjukkan bahwa semakin tinggi partisipasi penganggaran dan asimetri informasi mengakibatkan semakin tinggi senjangan anggaran, sedangkan semakin tinggi budaya organisasi dan komitmen organisasi mengakibatkan semakin rendah tingkat senjangan anggaran.

Kata Kunci: Partisipasi Penganggaran; Asimetri Informasi; Budaya Organisasi; Komitmen Organisasi; Senjangan Anggaran.

\section{Budgeting Participation, Information Asymmetry, Organizational Culture, Organizational Commitment and Budgetary Slack}

\begin{abstract}
The purpose of this study is to empirically examine the effect of budgetary participation, information asymmetry, organizational culture and organizational commitment on budgetary slack. This research was conducted in all OPDs in Tabanan Regency. The number of OPDs used was 40 OPDs and the number of sample used by 120 peoples. The data analysis technique used is multiple linear regression analysis. The results of this analysis indicate that budgetary participation and information asymmetry have a positive effect on budgetary slack while organizational culture and organizational commitment have a negative effect on budgetary slack. This shows that the higher budgetary participation and information asymmetry results in higher budgetary slack, while higher organizational culture and organizational commitment results in lower budgetary slack rates.
\end{abstract}

Keywords: Budgeting Participation; Information Asymmetry; Organizational Culture; Organizational Commitment; Budgetary Slack.

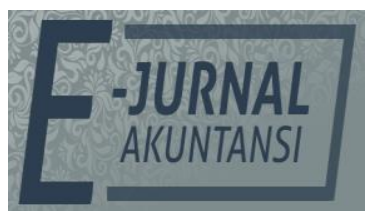

e-ISSN 2302-8556

Vol. 30 No. 12

Denpasar, Desember 2020 Hal. 3010-3027

DOI:

10.24843/EJA.2020.v30.i12.p02

PENGUTIPAN:

Narotama, I D. G. N. N. \&

Sujana, I K. (2020).

Partisipasi Penganggaran, Asimetri Informasi, Budaya

Organisasi, Komitmen Organisasi dan Senjangan

Anggaran. E-Jurnal

Akuntansi, 30(12), 3010-3027

RIWAYAT ARTIKEL:

Artikel Masuk: 17 Mei 2020

Artikel Diterima:

21 Juli 2020

Artikel dapat diakses : https://ojs.unud.ac.id/index.php/Akuntansi/index 


\section{PENDAHULUAN}

Proses penyusunan anggaran melibatkan banyak pihak, mulai dari manajemen tingkat atas sampai manajemen tingkat bawah. Masalah yang sering terjadi terdapat adanya keterlibatan orang-orang yang menciptakan anggaran yang tidak sesuai dengan jumlah biaya selama satu periode anggaran. Senjangan anggaran pada pemerintah daerah terjadi karena adanya komunikasi yang terjadi antara atasan dan bawahan tidak berjalan efektif sehingga adanya perilaku oportunistik dalam instansi pemerintah. Anggaran yang disusun dengan partisipasi anggaran yang salah akan menyebabkan kerugian bagi para pihak stakeholder dan pihak shareholder (Wardhana \& Gayatri, 2018).

Pemerintah daerah menginginkan setiap organisasi perangkat daerahnya memiliki kinerja yang benar dan bertanggung jawab dalam menjalankan tugas dan fungsinya, baik dalam hal perencanaan, pengorganisasian, pelaksanaan program, pengawasan dan evaluasi, termasuk didalamnya adalah pertanggungjawaban anggaran. Keterlibatan penyusun anggaran sangatlah dibutuhkan untuk meningkatkan komitmen dalam target anggaran. Pencapaian target anggaran tentunya merupakan salah satu tujuan yang ingin dicapai oleh mereka. Demi jenjang karir yang lebih tinggi di masa mendatang, penilaian kinerja hal tersebut memotivasi agen untuk melakukan senjangan anggaran. Dalam tahap persiapan dan perencanaan anggaran daerah juga sering terjadinya senjangan anggaran, karena anggaran kurang mencerminkan kebutuhan masyarakat. Senjangan anggaran akan menyebabkan bias dalam evaluasi kinerja agen pada unit pertanggungjawabannya dan berdampak pada kesalahan alokasi sumber daya.

Senjangan anggaran merupakan perbedaan jumlah anggaran yang diajukan oleh bawahan dengan jumlah estimasi yang terbaik dari organisasi. Estimasi yang dimaksud adalah anggaran yang sesungguhnya terjadi dan sesuai dengan kemampuan terbaik suatu organisasi (Sundari et al., 2015). Meirina (2018) menjelaskan bahwa tiga alasan utama agen melakukan senjangan anggaran, yaitu: (a) individu percaya bahwa hasil pekerjaan mereka terlihat bagus dimata atasan jika target yang telah direncanakan dapat tercapai, (b) senjangan anggaran selalu digunakan untuk mengatasi kondisi tidak pasti, dan (c) rencana angaran selalu dipotong dalam proses pengalokasian sumber daya. Penjelasan konsep senjangan anggaran dapat menggunakan pendekatan agency theory. Praktek senjangan anggaran dari perpektif agncy theory dipengaruhi oleh adanya konflik kepentingan antar agen dengan principal yang timbul ketika setiap pihak berusaha untuk mencapai kemakmuran yang dikehendakinya. Agency theory menjelaskan fenomena yang terjadi apabila atasan mendelegasikan wewenangnya kepada bawahan untuk melakukan tugas atau otoritas yang membuat keputusan (Kurniawan, 2015).

Fenomena yang terjadi di Kabupaten Tabanan yang tercantum pada halaman MEDIAPELANGI.com seorang oknum Pegawai Negeri Sipil (PNS) di Pemkab Tabanan menjadi tersangka kasus penggelapan dana PPB-P2 dan PPHBPHTB yang telah di jebloskan Kejari Tabanan ke Lembaga Permasyarakatan klas II B Tabanan. Tersangka diketahui oknum PNS di staf Bakeuda Kabupaten Tabanan. Tersangka telah menyebabkan kerugian PAD dan Negara sekitar 138.935.329,60, penahanan tersangka di lakukan jaksa sesuai KUHP karena 
ditakutkan tersangka melarikan diri, menghilangkan barang bukti serta mengulangi lagi perbuatanya.

Berdasarkan fenomena Berikut terdapat perbedaan antara jumlah anggaran yang direncanakan dengan jumlah realisasi anggaran yang sesungguhnya pada 1 dan 2 mengenai laporan anggaran dan realisasi pendapatan belanja daerah Kabupaten Tabanan tahun anggaran 2014 s.d 2018.

Tabel 1. Realisasi Pendapatan Kabupaten Tabanan Tahun Anggaran 2017 s.d 2018

\begin{tabular}{lllll}
\hline \multirow{2}{*}{ Tahun } & $\begin{array}{l}\text { Anggaran } \\
\text { Pendapatan }\end{array}$ & $\begin{array}{l}\text { Realisasi } \\
\text { Pendapatan }\end{array}$ & Selisih & (\%) \\
\hline 2017 & $1.913 .540 .384 .115,25$ & $1.871 .864 .102 .726,24$ & $41.676 .281 .389,01$ & $97,82 \%$ \\
2018 & $1.948 .668 .063 .171,11$ & $1.862 .277 .203 .959,96$ & $86.390 .859 .211,15$ & $95,57 \%$ \\
\hline
\end{tabular}

Sumber: Bakeuda Kabupaten Tabanan, 2020

Tabel 1, menunjukkan bahwa kinerja pemerintah Kabupaten Tabanan kurang optimal, karena dapat dilihat dari penetapan anggaran terjadi perbedaan jumlah antara anggaran yang direncanakan dengan realisasi anggaran yang sesungguhnya. Realisasi pendapatan daerah tahun 2017 dan 2018 lebih rendah dibandingkan dengan anggaran pendapatan daerah Kabupaten Tabanan. Hal ini terjadi karena adanya inflasi pada sektor pendapatan pajak, karena transaksi jual beli tanah mengalami penurunan akibat harga tanah yang tinggi yang memperngaruhi pendapatan daerah dan alokasi dana yang tidak maksimal dari APBN. Pendapatan daerah juga menunjukkan persentase yang tidak mencapai 100\% disebabkan kebijakan Donald Trump terkait penginapan Pan Pacific Nirwana yang terdapat di Tanah Lot yang merupakan sumber pendapatan dari pajak hotel telah dibongkar dan digantikan dengan penginapan Trump yang sampai saat ini dalam proses pembangunan sehingga tidak dapat dipungut pajaknya dan adanya letusan gunung agung. Jika dilihat kembali pada Tabel 1, realisasi belanja dari 2017 hingga 2018 berturut-turut selalu mengalami peningkatan dan presentase tidak mencapai $90 \%$ disebabkan adanya efisiensi dari pihak pemerintah.

Tabel 2. Realisasi Anggaran Belanja Daerah Kabupaten Tabanan Tahun Anggaran 2017-2018

\begin{tabular}{llllccl}
\hline \multirow{2}{*}{ Tahun } & $\begin{array}{l}\text { Anggaran Belanja } \\
\text { Daerah }\end{array}$ & $\begin{array}{l}\text { Realisasi } \\
\text { Daerah }\end{array}$ & Belanja & Selisih & (\%) \\
\hline 2017 & $2.184 .423 .902 .722,87$ & $1.861 .962 .379 .735,27$ & $322.461 .522 .987,60$ & $85,24 \%$ \\
2018 & $2.214 .812 .691 .827,97$ & $1.909 .975 .375 .775,88$ & $304.837 .316 .052,09$ & $86,24 \%$ \\
\hline Sumber:
\end{tabular}

Sumber: Bakeuda Kabupaten Tabanan, 2020

Berdasarkan Tabel 2, memperlihatkan telah terjadi fenomena perbedaan anggaran dan realisasi yang ditetapkan. Laporan realisasi anggaran belanja tahun 2017 dan 2018 menunjukkan bahwa jumlah anggaran yang ditetapkan kurang dari 100\% terealisasikan. Jika dilihat kembali pada Tabel 2, realisasi belanja dari 2017 hingga 2018 berturut-turut selalu mengalami peningkatan dan presentase tidak mencapai $90 \%$ disebabkan adanya efisiensi dari pihak pemerintah. Dilihat dari data tersebut anggaran diestimasi dengan sengaja agar jumlah yang tertera lebih tinggi atau lebih kurang dari yang seharusnya, sehingga dapat menimbulkan senjangan anggaran. Hal ini menunjukan bahwa belum seluruhnya realisasi anggaran dapat terserap oleh alokasi belanja rutin maupun belanja pembangunan 
yang menyebabkan sisa lebih perhitungan pada setiap anggaran di pemerintahan Kabupaten Tabanan. Adanya perbedaan anggaran yang telah direncanakan dengan realisasinya dapat menimbulkan dampak negatif pada organisasi sektor publik, karena alokasi sumber daya dan kinerja pemerintah kurang optimal (Sukayana \& Putri, 2019). Senjangan anggaran akan berdampak pada kesalahan alokasi sumber daya dan bersifat bias dalam evaluasi kinerja agen pada unit pertanggungjawabannya (Suartana, 2010:138). Kondisi ini diduga disebabkan oleh beberapa faktor antara lain partisipasi anggaran, asimetri informasi, budaya organisasi, dan komitmen organisasi yang sebelumnya telah diteliti oleh Dewi, (2014), Pamungkas et al., (2014), Dianthi \& Wirakusuma, (2017), (Wardhana \& Gayatri, 2018) dan Luhur \& Supadmi, (2019).

Partisipasi penganggaran dianggap faktor yang dapat mempengaruhi terjadinya senjangan anggaran. Partisipasi penganggaran merupakan proses di mana satuan kerja baik itu atasan maupun bawahan yang terlibat dan mempunyai perngaruh dalam menentukan target anggaran (Apriantini et al., 2014). Luhur (2019) menjelaskan bahwa semakin tingggi partisipasi yang terlibat dalam penyusunan anggaran akan menyebabkan dorongan individu melakukan senjangan anggaran. Dalam penyusunan anggaran individu menyalahgunakan wewenangnya agar mempermudah pencapaian target anggaran sehingga dapat merugikan organisasi tersebut. Individu merasakan tekanan dari anggaran yang ketat dan kegelisahan atas laporan kinerja yang dinilai buruk sehingga anggaran sering kali menghambat kemajuan karier mereka.

Penelitian yang berkaitan dengan partisipasi penganggaran dan senjangan anggaran telah menjadi perhatian banyak peneliti. Ardianti et al., (2015), Saputra \& Wijana Asmara Putra (2017), Yasa et al., (2017), Mertayani \& Suardikha (2017), Hikmahwati et al., (2018), Windiani et al., (2019), Luhur \& Supadmi (2019) menemukan bahwa partisipasi penganggaran berpengaruh terhadap senjangan anggaran. Semakin tinggi keterlibatan individu dalam penyusunan anggaran maka semakin tinggi terjadinya praktik senjangan anggaran. Sebaliknya, hasil penelitian yang ditemukan oleh Sujana (2010), Ardanari \& Putra (2014), Dewi \& Erawati (2014), dan Sulistyoningsih (2018) yang menemukan bahwa partisipasi penganggaran tidak berpengaruh pada senjangan anggaran. semakin tinggi keterlibatan individu dalam penyusunan anggaran makan semakin rendah terjadinya praktik senjangan anggaran.

Faktor lain yang dianggap mempengaruhi timbulnya senjangan anggaran adalah asimetri informasi. Asimetri informasi dalam teori agensi merupakan keadaan ketika bawahan (agent) memiliki informasi lebih banyak dibandingkan atasan (principal) sehingga prinsipal belum mampu mengetahui usaha yang telah dilakukan oleh agen dimana asimetri terjadi pada pihak prinsipal (pemerintah) dengan agen (Kepala OPD). Luhur (2019) menjelaskan bahwa informasi asimetri adalah kondisi dimana bawahan memiliki informasi yang lebih banyak dibandingkan atasan, maupun sebaliknya. Bila kemungkinan yang pertama terjadi, akan muncul tuntutan yang lebih besar dari atasan kepada bawahan mengenai pencapaian anggaran yang menurut bawahan terlalu tinggi. Namun, kemungkinan yang kedua terjadi, bawahan akan menyatakan target lebih rendah dari pada yang akan dicapai. Kondisi ini menyebabkan diterapkan sistem anggaran partisipatif agar informasi yang dimiliki bawahan dapat 
dikomunikasikan dengan atasan. Perbedaan informasi ini menjadi faktor utama adanya senjangan anggaran. Penelitian yang berkaitan mengenai pengaruh asimetri informasi pada senjangan anggaran telah dilakukan oleh (Sujana, 2010) yang menemukan bahwa asimetri informasi berpengaruh pada senjangan anggaran. Selaras dengan penelitian Sujana (2010) penelitian yang dilakukan Ardanari \& Putra (2014), (Saputra \& Wijana Asmara Putra, 2017), Hikmahwati et al., (2018), Ayuni \& Erawati (2018), Windiani (2019), Luhur \& Supadmi (2019) menemukan bahwa asimetri infromasi berpengaruh terhadap senjangan anggaran. Artinya semakin tinggi asimetri informasi yang terjadi antara atasan dan bawahan maka semakin tinggi senjangan anggaran yang terjadi. Sebaliknya, hasil penelitian Pello (2014), Mukaromah \& Suryandari (2015), Irfan et al., (2016), Ardiyani \& Sukirno (2017) dan Sulistyoningsih (2018) menemukan bahwa asimetri informasi tidak berpengaruh terhadap senjangan anggaran. Artinya semakin tinggi asimetri informasi yang terjadi antara atasan dan bawahan maka semakin rendah senjangan anggaran yang terjadi.

Budaya organisasi termasuk faktor yang mempengaruhi senjangan anggaran. Dalam budaya organisasi birokrasi berkaitan erat dengan pelayanan publik, karena kegiatan aparatur publik harus berpedoman pada peraturan normatif yang telah ditetapkan oleh organisasi publik. Adapun budaya organisasi telah menjadi cara dalam melakukan pekerjaan dan memberikan tanggapan pada kondisi lingkungan organisasi, dalam hal ini proses penyusunan anggaran. Dewi (2014) menjelaskan bahwa secara teoritis organisasi yang memiliki struktur terdesentralisasi mampu memberikan pelayanan publik secara efektif dan efisien. Hal tersebut akan memininalisir kesenjangan peran antara organisasi pusat dengan organisasi pelaksanaan kegiatan.

Budaya organisasi yang diterapkan di pemerintah Indonesia memliki karakter budaya model birokratis. Budaya birokratis mampu membentuk identitas individu di dalam organisasi dan organisasi itu sendiri. Identitas tersebut merupakan pembeda dari satu organisasi ke organisasi lainnya. Pembeda tersebut dapat berfungsi sebagai pengendali perilaku anggota organisasi (Ardinasari, 2017). Pemerintah Daerah Tabanan memiliki budaya organisasi yang diterapkan dalam lingkungan kerja yaitu SERASI (Sejahtera, Aman dan Berprestasi). Diharapkan dengan perumusan nilai-nilai tersebut, akan tercapainya pemerintahan yang good governance di Kabupaten Tabanan, salah satunya mengantisipasi senjangan anggaran. Maharani (2015) menjelaskan bahwa budaya organisasi merupakan suatu kumpulan sikap, cara pandang, kebiasaan dalam menanggapi situasi lingkungan yang dapat dimanfaatkan sebagai pendorong komitmen karyawan. Pamungkas et al., (2014) menjelaskan bahwa organisasi yang memiliki budaya organisasi yang kuat akan berupaya mengimplementasikan anggaran sesuai dengan apa adanya tanpa ada tujuan lain, sehingga mereka tidak akan melakukan sesuatu hal yang dapat dikatakan menyimpang yang dapat merugikan organisasi tempat mereka bekerja. Penjelasan tersebut sejalan dengan peneltian yang dilakukan oleh Pamungkas et al., (2014), Prawira (2016), Mufarrihah (2017), Koeswardhana \& Saprudin (2019) menemukan budaya organisasi berpengaruh terhadap senjangan anggaran. Semakin tinggi budaya organisasi yang dianut organisasi maka senjangan anggaran yang terjadi semakin tinggi. Sedangkan, hasil berbeda dalam penelitian Hasanah \& Suartana (2014) 
Huda et al., (2014), Maharani \& Ardiana (2015), Asih et al., (2016) Antari \& Sukartha (2017), Ardinasari (2017), Dianthi \& Wirakusuma, (2017), Lestiana a Sari (2017), Irfan (2017), Wardhana \& Gayatri (2018) dan Widyasari \& Ratnadi (2018) menemukan budaya organisasi tidak bepengaruh terhadap senjangan anggaran. Semakin tinggi budaya organisasi yang dianut organisasi maka senjangan anggaran yang terjadi semakin rendah.

Komitmen organisasi juga Faktor lain yang memperngaruhi senjangan anggaran. Komitmen organisasi menunjukkan keyakinan dan dukungan yang kuat terhadap nilai dan sasaran yang akan dicapai organisasi (Luhur, 2019). Nitiari (2014) menjelaskan bahwa semakin tinggi komitmen, menyebabkan menurunnya senjangan anggaran. Hal ini menggambarkan karyawan yang memiliki komitmen organisasi tinggi akan menggunakan anggaran untuk mencapai tujuan organisasi. Sedangkan karyawan dengan komitmen organisasi yang rendah akan menggunakan anggaran untuk kepentingan diri sendiri. Penelitian yang dilakukan Huseno (2017), Fitra (2017), Saputra (2017), Prakasa (2016) dan Luhur (2019) menemukan bahwa komitmen organisasi berpengangruh terhadap senjangan anggaran. Artinya semakin tinggi komitmen organisasi didalam diri individu menyebabkan semakin tinggi kemungkinan terjadinya senjangan anggaran. Sedangkan hasil penelitian Sujana (2010), Dewi \& Erawati, (2014) Nitiari \& Yadnyana (2014), Widodo (2015), Sari \& Putra (2017), Dianthi \& Wirakusuma (2017), Dianthi \& Wirakusuma, (2017), Widyasari \& Ratnadi (2018), Ayuni \& Erawati, (2018), Wardhana \& Gayatri (2018) dan Windiani et al., (2019) menemukan bahwa komitmen organisasi tidak bepengaruh terhadap senjangan anggaran. Artinya semakin tinggi komitmen organisasi didalam diri individu menyebabkan semakin rendah kemungkinan terjadinya senjangan anggaran.

Adanya ketidakkonsistenan dari hasil penelitian terdahulu mengenai faktor-faktor yang mempengaruhi senjangan anggaran dan data APBD Pemerintah Kabupaten Tabanan yang diduga telah terjadi senjangan anggaran, memotivasi penulis melakukan penelitian mengenai pengaruh partisipasi anggaran, asimetri informasi, budaya organisasi dan komitmen organisasi pada senjangan anggaran di Organisasi Perangkat Daerah Kabupaten Tabanan.

Partisipasi yang tinggi akan memberikan kesempatan yang lebih besar kepada individu untuk melakukan senjangan anggaran, sebaliknya partisipasi yang rendah kesempatan yang didapat individu untuk melakukan senjangan anggaran terbatas sehingga senjangan anggaran juga rendah. Pernyataan tersebut sesuai dengan penelitian yang dilakukan oleh Ardianti et al., (2015), Saputra \& Wijana Asmara Putra (2017), Yasa et al., (2017), Mertayani \& Suardikha (2017) Luhur \& Supadmi (2019) yang menemukan bahwa partisipasi anggaran berpengaruh pada senjangan anggaran.

Berdasarkan landasan teori dan beberapa penelitian sebelumnya disimpulkan bahwa partisipasi dalam proses penyusunan anggaran beperngaruh pada senjangan anggaran semakin tinggi partisipasi anggaran yang ada maka akan semakin memperbesar peluang terjadinya senjangan anggaran. Sebaliknya semakin rendah partisipasi anggaran maka semakin memperkecil terjadinya senjangan anggaran. oleh karena itu, hipotesis yang diruamuskan sebagai berikut. $\mathrm{H}_{1}$ : Partisipasi anggaran berpengaruh positif pada senjangan anggaran. 
Asimetri informasi memunculkan peluang kepada penyusun anggaran dalam mempengaruhi anggaran yang tidak sesuai dengen yang diinginkan atasan. Bawahan mungkin saja mempunyi informasi pribadi yang disembunyikan atau tidak memberikan semua informasi yang relevan yang mereka miliki kepada atasan. Kondisi inilah yang digunakan bawahan untuk melaporkan informasi yang berbeda dari yang sebanarnya, sehingga memunculkan senjangan anggaran dengan tujuan untuk mempermudah pencapaian target yang diharapkan (Luhur \& Supadmi, 2019). Pernyataan tersebut sesuai dengan hasil penelitian Ardanari \& Putra (2014), Saputra \& Wijana Asmara Putra (2017), Hikmahwati et al., (2018), Ayuni \& Erawati (2018), dan Windiani et al., (2019) yang menemukan bahwa informasi asimetri berpengaruh pada senjangan anggaran.

Berdasarkan landasan teori dan beberapa penelitian sebelumnya disimpulkan bahwa asimetri informasi digunakan untuk membuat anggaran yang mudah dicapai dengan menciptakan senjangan anggaran oleh bawahan agar kinerja mereka terlihat bagus dimata atasan. Semakin tinggi asimetri informasi maka semakin memperbesar terjadinya senjangan sebaliknya, semakin rendah asimetri informasi, akan memperkecil terjadinya senjangan anggaran. oleh karena itu, hipotesis yang dirumuskan sebagai berikut.

$\mathrm{H}_{2}$ : Asimetri informasi berpengaruh positif pada senjangan anggaran.

Budaya organisasi adalah suatu sistem nilai yang diperoleh dan dikembangkan oleh organisasi dan pola kebiasaan dan falsafah dasar pendirinya, yang terbentuk menjadi aturan yang digunakan sebagai pedoman dalam berfikir dan bertindak dalam mencapai tujuan organisasi (Robins, 2015:355). Organisasi yang memiliki budaya organisasi yang kuat akan berupaya mengimplementasikan anggaran sesuai dengan apa adanya tanpa tujuan lain. Sebaliknya, organisasi yang yang budaya organisasi yang lemah akan melakukan sesuatu yang dapat dikatakan menyimpang (senjangan) yang dapat merugikan organisasi tempat bekerja (Wardhana, 2018). Maharani \& Ardiana (2015) menjelaskan bahwa budaya organisasi yang kuat mengurangi terjadinya senjangan anggaran. Hal tersebut karena nilai-nilai organisasi dapat diterima oleh anggota sehingga mereka berupaya mengimplementasikan anggaran sesuai dengan apa adanya tanpa ada maksud lain. Pernyataan tersebut sesuai dengan hasil penelitian Hasanah \& Suartana (2014) Dianthi \& Wirakusuma (2017), Antari \& Sukartha (2017), Ardinasari (2017), Lestiana \& Sari (2017), dan Widyasari \& Ratnadi (2018) yang menemukan bahwa budaya organisasi tidak berpengaruh pada senjangan anggaran. Berdasarkan landasan teori dan penelitian sebelumnya, disimpulkan bahwa semakin tinggi budaya organisasi maka memperkecil peluang terjadinya senjangan anggaran karena nilai-nilai budaya yang tertanam dalam organisasi tercermin dari perilaku anggotanya yang mengimplementasikan anggaran dengan apa adanya tanpa melakukan perilaku yang menyimpang dari tujuan organisasi. Oleh karena itu, hipotesis yang dirumuskan sebagai berikut. $\mathrm{H}_{3}$ : Budaya organisasi berpengaruh negatif pada senjangan anggaran.

Komitmen organisasi mencerminkan keyakinan karyawan terlibat dalam organisasinya dan berkeinginan untuk tetap menjadi anggotanya, dimana didalamnya mengandung sikap kesetiaan dan kesediaan karyawan untuk bekerja secara maksimal bagi organisasi tempat karyawan tersebut bekerja. Komitmen organisasi mencerminkan adanya keyakinan serta dukungan kuat terhadap nilai 
dan sasaran yang ingin dicapai oleh organisasi (Mowday et al., 1979). Besarnya komitmen agent tergantung pada sejauhmana ia mementingkan kepentingan organisasi dibandingkan dengan kepentingan dirinya sendiri. Individu yang memiliki komitmen organisasi tinggi akan menggunakan anggaran untuk tujuan organisasi.

Sebaliknya, individu dengan komitmen organisasi yang rendah akan menggunakan anggaran untuk mengejar kepentingan pribadi (Widodo, 2015). Wardhana \& Gayatri (2018) menyatakan bahwa penyusun anggaran dengan komitmen organisasi yang tinggi akan mengurangi terjadinya senjangan anggaran. Hal ini karena para penyusun anggaran lebih mementingkan tujuan organisasi dengan tujuan pribadinya. Pernyataan tersebut sejalan dengan hasil penelitian Nitiari \& Yadnyana (2014), Dewi \& Erawati, (2014), Nitiari \& Yadnyana (2014), Sari \& Putra (2017), Dianthi \& Wirakusuma, (2017) Widyasari \& Ratnadi (2018), Ayuni \& Erawati, (2018) dan Windiani et al., (2019) yang menemukan bahwa komitmen organisasi tidak berpengaruh pada senjangan anggaran. Berdasarkan landasan teori dan penelitian sebelumnya, disimpulkan bahwa semakin tinggi komitmen organisasi dapat memperkecil peluang terjadinya senjangan anggaran karena individu yang loyal terhadap organisasinya akan bekerja secara maksimal dalam menyusun anggaran demi kepentingan organisasi. Oleh karena itu, hipotesis yang dirumuskan sebagai berikut.

$\mathrm{H}_{4}$ : Komitmen organisasi berpengaruh negatif pada senjangan anggaran.

\section{METODE PENELITIAN}

Lokasi Penelitian ini akan dilakukan di OPD Kabupaten Tabanan yang berjumlah 38 OPD. Lokasi ini dipilih karena mempunyai struktur penganggaran yang terorganisir dengan baik selain itu adanya pendanaan dari pemerintah pusat ke pemerintah daerah cenderung menyebabkan ketergantungan kuangan yang menimbulkan terjadinya senjangan anggaran, disamping itu pemerintah bertanggung jawab terhadap pengelolaan keuangan kepada masyarakat dan sepengetahuan peniliti belum ada penelitian serupa yang meneliti di OPD Kabupaten Tabanan terkait penelitian ini untuk setahun terakhir, sehingga peneliti tertarik dan memutuskan untuk meneliti di wilayah tersebut.

Populasi dalam penelitian ini adalah penjabat yang berwenang dalam penyusunan anggaran pada Organisasi Perangkat Daerah (OPD) Kabupaten Tabanan. Sesuai dengan peraturan menteri dalam negeri No. 13 Tahun 2006 tentang Pedoman Pengelolaan Keuangan Daerah menjelaskan pengelolaan keuangan daerah merupakan keseluruhan kegiatan yang meliputi perencanaan, pelaksanaan, penatausahaan, pelaporan, pertanggungjawaban dan pengawasan keuangan daerah. Kepala OPD selaku yang menyusun rencana, melaksanakan dan mempertanggungjawabkan anggaran. Kepala OPD menetapkan Kepala Sub Bagian perencanaan dan pelaporan selaku Penjabat Pelaksana Teknis Kegiatan (PPTK) yang menghimpun dan bertanggung jawab dalam penyusunan anggaran. Kepala Sub Bagian Keuangan selaku Penjabat Penatausahaan Keuangan (PPK) yang bertugas untuk merencanakan, melaksanakan, menatausahakan dan melaporkan pertanggungjawaban pengelolaan keuangan OPD. Oleh karena itu, sampel dalam penelitian ini diambil dari seluruh Kepala OPD, Kepala Sub Bagian 
Perencanaan dan Pelaporan, serta Kepala Sub bagian Keuangan di setiap OPD Kabupaten Tabanan.

Teknik analisis yang digunakan dalam penelitian ini adalah analisis statistic deskriptif dan teknik analisis regresi berganda bertujuan untuk mengetahui besarnya pengaruh partisipasi penganggaran, asimetri informasi, budaya organisasi, dan komitmen organisasi, pada senjangan anggaran. analisis ini dilakukan dengan menggunakan bantuan program Statistical Package for Social Science (SPSS). Persamaan matematis untuk hubungan yang dihipotesiskan dapat dirumuskan sebagai berikut:

$\mathrm{Y}=\alpha+\beta 1 \mathrm{X} 1+\beta 2 \mathrm{X} 2+\beta 3 \mathrm{X} 3+\beta 4 \mathrm{X} 4+\varepsilon$

Keterangan:

$\mathrm{Y} \quad=$ Senjangan Anggaran

$\alpha \quad=$ Konstanta

$\beta 1=$ Koefisien regresi variabel partisipasi anggaran

$\beta 2=$ Koefisien regresi variabel asimetri informasi

$\beta 3=$ Koefisien regresi variabel budaya organisasi

$\beta 4=$ Koefisien regresi variabel komitmen organisasi

$\mathrm{X} 1=$ Partisipasi anggaran

$\mathrm{X} 2=$ Asimetri informasi

$\mathrm{X} 3=$ Budaya organisasi

$\mathrm{X} 4=$ Komitmen organisasi

$\varepsilon \quad=$ Error

\section{HASIL DAN PEMBAHASAN}

Data responden yang diperoleh dari hasil kuesioner yang telah disebarkan berdasarkan analisis statistik deskriptif Tabel 3, sebagai berikut.

Tabel 3. Hasil Analisis Statistik Deskriptif

\begin{tabular}{llllll}
\hline & $\mathrm{N}$ & Minimum & Maximum & Mean & Std. Deviation \\
\hline Partisipasi Anggaran & 112 & 1,60 & 4,00 & 2,9268 & 0,44113 \\
Asimetri Informasi & 112 & 2,20 & 4,00 & 3,2098 & 0,38507 \\
Budaya Organisasi & 112 & 2,70 & 4,00 & 3,3080 & 0,37008 \\
Komitmen Organisasi & 112 & 2,00 & 3,70 & 3,0107 & 0,31916 \\
Senjangan Anggaran & 112 & 1,00 & 3,80 & 2,3500 & 0,51605 \\
\hline
\end{tabular}

Sumber: Data Penelitian, 2020

Variabel partisipasi penganggaran memiliki nilai minimum sebesar 1,60 dan nilai maksimum sebesar 4,00. Variabel partisipasi penganggaran yang diukur dengan 5 pertanyaan dengan bantuan skala likert 4 poin memiliki nilai rata-rata sebesar 2,9268 dengan nilai standar deviasi variabel partisipasi penganggaran sebesar 0,44113. Nilai standar deviasi lebih rendah dibandingkan dengan nilai rata-rata, hal ini berarti sebaran data terkait dengan partisipasi penganggaran sudah merata, sehingga dapat dikatakan bahwa sebagian besar minat anggota untuk berpartisipasi dalam pembauatan anggaran cenderung tinggi.

Variabel informasi asimetri memiliki nilai minimum sebesar 2,20 dan nilai maksimum sebesar 4,00. Variabel asimetri informasi yang diukur dengan 6 item pertanyaan dengan bantuan skala likert 4 memiliki nilai rata-rata sebesar 3,2098, dengan nilai deviasi variabel asimetri informasi 0,38507. Nilai standar deviasi ini 
lebih rendah dibandingkan dengan nilai rata-rata, hal ini berarti sebaran data sudah merata, sehingga dapat dikatakan bahwa sebagaian besar asimetri informasi di dalam anggota yang terjadi saat proses pembuatan anggaran cenderung tinggi.

Variabel budaya organisasi memiliki nilai minimum sebesar 2,70 dan nilai maksimum 4,00. Variabel budaya organisasi yang diukur dengan 7 item pertanyaan dengan bantuan skala likert 4 memiliki nilai rata-rata sebesar 3,3080, dengan nilai standar deviasi variabel budaya organisasi sebesar 0,37008. Nilai standar deviasi ini lebih rendah dibandingkan dengan nilai rata-rata, hal ini berarti sebesaran data terkait budaya organisasi sudah merata, sehingga dapat dikatakan bahwa sebagai besar anggota di OPD Tabanan memiliki budaya organisasi cenderung tinggi.

Variabel komitmen organisasi memiliki nilai minimum sebesar 2,00 dan nilai maksimum sebesar 3,70. Variabel komitmen organisasi yang diukur dengan 7 item pertanyaan dengan bantuan skala likert 4 memiliki nilai rata-rata sebesar 3,0107, dengan nilai standar deviasi variabel komitmen organisasi 0,31916. Nilai standar deviasi ini lebih rendah dibandingkan dengan nilai rata-rata, hal ini berarti sebaran data terkait komitmen organisasi sudah merata, sehingga dapat dikatakan setiap anggota di OPD Tabanan berkomitmen dalam menjalankan tugas cenderung tinggi

Variabel senjangan anggaran memiliki skor minimum 1,00 dan nilai maksimum sebesar 3,80. Variabel senjangan anggaran yang diukur dengan 5 item pertanyaan dengan bantuan skala likert 4 memiliki nilai rata-rata sebesar 2,3500, dengan nilai standar deviasi variabel senjangan anggaran sebesar 0,51605. Nilai standar deviasi ini lebih rendah dibandingkan dengan nilai rata-rata, hal ini berarti sebaran data terkait senjangan anggaran sudah merata, sehingga dapat dikatakan tingkat senjangan anggaran yang terjadi di OPD Tabanan cenderung tinggi.

Perhitungan koefisien regresi linier berganda dilakukan dengan analisis regresi melalui software SPSS 18.0 for Windows, diperoleh hasil yang ditunjukan pada Tabel 4, sebagai berikut.

Tabel 4. Hasil Analisis Regresi Linier Berganda

\begin{tabular}{llllll}
\hline Model & \multicolumn{2}{l}{$\begin{array}{l}\text { Unstandardized } \\
\text { Coefficients }\end{array}$} & \multicolumn{2}{l}{$\begin{array}{l}\text { Standardized } \\
\text { Coefficients }\end{array}$} & \\
\cline { 2 - 5 } & $\mathrm{B}$ & Std. Error & Beta & T & Sig. \\
\hline (Constant) & 15,028 & 4.868 & & 3.087 & 0,003 \\
Partisipasi anggaran & 0,225 & 0,110 & 0,193 & 2.041 & 0,044 \\
Asimetri informasi & 0,359 & 0,115 & 0,324 & 3.133 & 0,002 \\
Budaya organisasi & $-0,349$ & 0,112 & $-0,348$ & -3.116 & 0,002 \\
Komitmen organisasi & $-0,257$ & 0,122 & $-0,227$ & -2.114 & 0,037 \\
R Square & 0,202 & & & & \\
Adjusted R Square & 0,172 & & & & \\
F Statistik & 6,767 & & & & \\
Signifikansi Uji F & 0,000 & & & & \\
\hline
\end{tabular}

Sumber: Data Penelitian, 2020

Berdasarkan hasil analisis regresi linier berganda seperti yang disajikan pada Tabel 4, maka dapat dibuat persamaan regresi sebagai berikut.

$$
\mathrm{Y}=15,028+0,225 \mathrm{X}_{1}+0,359 \mathrm{X}_{2}-0,349 \mathrm{X}_{3}-0,257 \mathrm{X}_{4}
$$


Nilai signifikansi masing-masing variabel bebas kurang dari 0,05. Hal ini menunjukkan bahwa semua variabel bebas memiliki pengaruh yang signifikan terhadap variabel terikat.

Hasil uji koefisien determinasi dalam penelitian ini dapat dilihat dalam Tabel 5, sebagai berikut.

Tabel 5. Hasil Uji Koefisien Determinasi

\begin{tabular}{clllll}
\hline Model & & R Square & Adjusted R Square & $\begin{array}{l}\text { Std. Error of the } \\
\text { Estimate }\end{array}$ & \\
\hline 1 & $\mathrm{R}$ & $\mathrm{R}$ S & 0,202 & 0,172 & 2.34780 \\
\hline
\end{tabular}

Sumber: Data Penelitian, 2020

Besarnya Tabel 5, pengaruh variabel bebas terhadap variabel terikat yang ditunjukkan oleh nilai determinasi total (R Square sebesar 0,202 mempunyai arti bahwa sebesar 20,2 persen variasi Senjangan anggaran dipengaruhi oleh variasi partisipasi anggaran, asimetri informasi, budaya organisasi, dan komitmen organisasi, sedangkan sisanya sebesar 79,8 persen djelaskan oleh faktor lain yang tidak dimasukkan ke dalam model.

Uji kelayakan model regresi bertujuan untuk mengetahui apakah semua variabel bebas yang diidentifikasi (partisipasi anggaran, asimetri informasi, budaya organisasi, komitmen organisasi, dan sanksi perpajakan) tepat digunakan memprediksi senjangan anggaran. Uji ini sering juga disebut dengan uji F seperti yang ditunjukkan dalam Tabel 6.

Tabel 6. Hasil Uji F

\begin{tabular}{lllllll}
\hline Model & & Sum of Squares & $d f$ & Mean Square & F & Sig. \\
\hline 1 & Regression & 149.200 & 4 & 37.300 & 6.767 & 0,000 \\
& Residual & 589.800 & 107 & 5.512 & & \\
& Total & 739.000 & 111 & & & \\
\hline
\end{tabular}

Sumber: Data Penelitian, 2020

Hasil pengolahan data pada Tabel 6, dengan menggunakan program SPSS

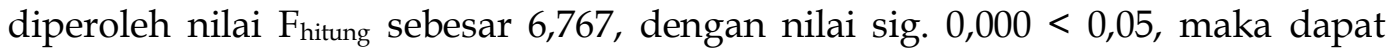
disimpulkan bahwa pada kelompok yang diuji memiliki perbedaan yang nyata (signifikan). Hasil ini mempunyai arti bahwa secara simultan atau secara bersamaan variabel Partisipasi anggaran, Asimetri informasi, Budaya organisasi, dan Komitmen organisasi berpengaruh signifikan terhadap senjangan anggaran.

Berdasarkan hasil analisis pengaruh Partisipasi anggaran terhadap Senjangan anggaran diperoleh nilai Signifikasi sebesar 0,044 dengan nilai koefisien regresi positif sebesar 0,225. Nilai Signifikansi 0,044 < 0,050 mengindikasikan bahwa $\mathrm{H}_{1}$ diterima. Hasil ini mempunyai arti bahwa Partisipasi anggaran berpengaruh positif dan signifikan terhadap Senjangan anggaran.

Partisipasi yang tinggi dalam proses penyusunan anggaran akan memberikan kesempatan yang lebih besar kepada bawahan untuk melakukan senjangan dan sebaliknya ketika partisipasi rendah harapan untuk melakukan senjangan anggaran dibatasi sehingga senjangan anggaran juga rendah. Hasil analisis menunjukkan bahwa partisipasi penganggaran berpengaruh positif dan signifikan terhadap senjangan anggaran. Hal ini berarti bahwa semakin rendah tingkat partisipasi penganggaran maka tingkat senjangan anggaran yang timbul akan semakin rendah, begitu pula sebaliknya partisipasi penganggaran yang 
tinggi dari bawahan, maka tingkat senjangan anggaran yang timbul akan semakin tinggi.

Hasil penelitian ini mendukung beberapa penelitian sebelumnya dan konsisten dengan hasil penelitian yang dilakukan oleh Ardianti et al., (2015), Saputra (2017), Yasa et al., (2017), Mertayani (2017) dan Luhur (2019) yang memperoleh hasil bahwa partisipasi berpengaruh positif dan signifikan terhadap senjangan anggaran. Adanya partisipasi penganggaran memberikan peluang bagi mereka untuk melonggarkan anggaran atau sengaja menciptkan senjangan, agar anggaran yang mereka susun mudah dicapai.

Berdasarkan hasil analisis pengaruh asimetri informasi terhadap senjangan anggaran diperoleh nilai signifikansi sebesar 0,002 dengan nilai koefisien regresi positif sebesar 0,359. Nilai Signifikansi 0,002 $<0,05$ mengindikasikan bahwa $\mathrm{H}_{2}$ diterima. Hasil ini mempunyai arti bahwa Asimetri informasi berpengaruh positif dan signifikan terhadap Senjangan anggaran.

Asimetri informasi merupakan perbedaan informasi yang dimiliki oleh atasan dengan bawahan, dalam hal ini yaitu perbedaan informasi yang dimiliki oleh pemimpin Organisasi Perangkat Daerah (OPD) dengan pegawai yang terlibat dalam penyusunan anggaran OPD. Hasil analisis dalam penelitian ini menunjukkan bahwa asimetri informasi berpengaruh positif dan signifikan terhadap senjangan anggaran. Hal ini berarti bahwa semakin tinggi tingkat asimetri informasi maka tingkat senjangan anggaran yang timbul akan semakin tinggi, begitu pula sebaliknya ketika asimetri informasi rendah maka senjangan yang terjadi juga rendah. Sehingga akan ada kemungkinan mereka akan melonggarkan anggaran atau sengaja menciptakan senjangan, agar anggaran yang mereka susun mudah tercapai.

Hasil penelitian ini mendukung beberapa penelitian sebelumnya dan konsisten dengan penelitian yang dilakukan oleh Ardanari (2014), Saputra (2017), Hikmahwati et al., (2018) dan Windiani et al., (2019) yang memperoleh hasil bahwa asimetri informasi berpengaruh positif dan signifikan terhadap senjangan anggaran. Adanya asimetri informasi memberikan peluang pada penyusun anggaran untuk mempengaruhi anggaran yang mungkin tidak sesuai dengan keinginan atasan. Biasanya penyusun anggaran akan menganggarkan sumber daya yang melebihi dari kebutuhan sebenarnya dengan maksud untuk memenuhi tujuan-tujuan mereka. Kondisi ini secara keseluruhan dapat menimbulkan kesalahan alokasi sumber daya yang dimiliki organisasi. Risiko lain dari asimetri informasi adalah penyusun anggaran bisa jadi mendistorsi informasi dengan tujuan untuk menurunkan ekspektasi atasan terhadap kinerja mereka.

Berdasarkan hasil analisis pengaruh Budaya organisasi terhadap Senjangan anggaran diperoleh nilai signifikansi sebesar 0,002 dengan nilai koefisien regresi negatif sebesar -0,349. Nilai signifikansi 0,002 $<0,050$ mengindikasikan bahwa $\mathrm{H}_{3}$ diterima. Hasil ini mempunyai arti bahwa Budaya organisasi berpengaruh negatif dan signifikan terhadap Senjangan anggaran.

Budaya organisasi merupakan suatu karakteristik pada sebuah organisasi dan menjadi pedoman yang diciptakan dan dikembangkan oleh individu yang bekerja dalam suatu organisasi yang dipahami dan diterima oleh semua anggota sebagai nilai-nilai yang harus dipertahankan dan diturunkan kepada setiap anggota baru. Hasil analisis dalam penelitian ini menunjukkan bahwa budaya 
organisasi berpengaruh negatif terhadap senjangan anggaran, berarti semakin tinggi tingkat budaya organisasi yang dianut suatu organisasi maka tingkat senjangan anggaran yang terjadi semakin rendah, begitu pula sebaliknya jika budaya organisasi rendah maka tingkat senjangan anggara yang terjadi akan semakin tinggi. Hal ini karena setiap individu sudah memahami nilai-nilai dalam pedoman bekerja dalam suatu organisasi sehingga individu melaksanakan pekerjaan sesuai dengan tujuan organisasi bukan untuk kepentingan pribadi.

Hasil ini mendukung beberapa penelitian sebelumnya dan konsisten dengan hasil penelitian yang dilakukan oleh Hasanah (2014), Dianthi (2017), Antari (2017), Lestiana (2017) dan Widyasari (2018) yang menjelaskan bahwa budaya organisasi berpengaruh negatif terhadap senjangan anggaran. uraian tersebut menunjukkan peningkatan dan penurunan senjangan anggaran tergantung sejauh mana individu mau memahami nilai-nilai yang ada diorganisasi dalam melaksanakan kegiatan dan tidak didasarkan keingin melakukan suatu kecurangan yang dapat merugikan organisasi.

Berdasarkan hasil analisis pengaruh Komitmen organisasi terhadap Senjangan anggaran diperoleh nilai signifikansi sebesar 0,037 dengan nilai koefisien regresi negatif sebesar -0,257. Nilai signifikansi 0,037 $<0,05$ mengindikasikan bahwa $\mathrm{H}_{4}$ diterima. Hasil ini mempunyai arti bahwa Komitmen organisasi berpengaruh negatif dan signifikan terhadap Senjangan anggaran.

Komitmen organisasi ialah sikap karyawan yang tertarik dengan tujuan, nilai dan sasaran organisasi yang ditunjukan dengan adanya penerimaan individu atas nilai dan tujuan organisasi serta memiliki keinginan untuk bekerjasama dengan organisasi dan kesediaan bekerja keras untuk organisasi sehingga membuat individu betah dan tetap ingin bertahan diorganisasi tersebut demi tercapainya tujuan dan kelangsungan organisasi. Hasil analisis dalam penelitian ini menunjukkan bahwa komitmen organisasi berpengaruh negatif terhadap senjangan anggaran, berarti bahwa semakin tinggi tingkat komitmen organisasi maka tingkat senjangan anggaran yang timbul akan semakin rendah, begitu pula sebaliknya jika komitmen organisasi rendah maka tingkat senjangan anggaran yang timbul akan semakin tinggi. Hal ini terjadi karena saat individu yang loyal terhadap organisasi, maka individu akan bekerja secara maksimal untuk mewujudkan tujuan organisasi.

Hasil penelitian ini mendukung beberapa penelitian sebelumnya dan konsisten dengan hasil penelitian Nitiari (2014), Dewi (2014), Sari (2017), Dianthi (2017), Widyasari (2018) dan Ayuni (2018) yang menjelaskan bahwa komitmen organisasi berpengaruh negatif terhadap senjangan anggaran. Uraian tersebut menunjukan bahwa peningkatan atau penurunan senjangan anggaran tergantung pada sejauh mana individu memetingkan bekerja untuk kepentingan organisasinya atau untuk kepentingan diri sendiri. Hal ini merupakan bentuk keinginan dari komitmen organisasi yang dimiliki individu tersebut. Ketika individu memiliki ikatan emosional terhadap organisasi yang meliputi dukungan moral dan tekad dari dalam diri untuk mengabdi pada organisasi, maka hal tersebut akan menumbuhkan komitmen organisasi. 


\section{SIMPULAN}

Penelitian ini diharapkan dapat memberikan kontribusi mengenai pengaruh partisipasi penganggaran, asimetri informasi, budaya organisasi dan komitmen organisasi pada senjangan anggaran di OPD Kabupaten Tabanan. Terdapat bukti empiris dalam penelitian ini, yaitu partisipasi penganggaran dan asimetri informasi berpengaruh positif pada senjangan anggaran, serta budaya organisasi dan komitmen organisasi berpengaruh negatif pada senjangan anggaran.

Hasil penelitian ini mendukung teori keagenan yang menjelaskan bahwa para penyusun anggaran dapat bertindak oportunistik sesuai dengan kepentingan individu itu sendiri melalui partisipasi penganggaran untuk menghindari risiko apa bila target anggaran tidak dapat tercapai dan asimetri informasi untuk menyembunyikan informasi pribadi yang tidak diketahui atasan. Hasil penelitian ini juga menyatakan bahwa budaya organisasi dan komitmen organisasi berpengaruh negatif pada senjangan anggaran sehingga tidak mendukung Theory of Behavior (TPB) yang menjelaskan bahwa individu dalam suatu organisasi dapat bertindak berdasarkan intens atau niatnya hanya jika ia memiliki kontrol terhadap perilakunya sendiri unuk melakukan kecurangan yang menyebabkan kerugian bagi organisasi.

Hasil penelitian ini mampu memberikan tambahan masukan dan informasi bagi pihak-pihak yang terkait dalam penyusunan anggaran pada OPD Kabupaten Tabanan. Bagi para penyusun anggaran di OPD Kabupaten Tabanan agar lebih selektif dalam menemukan indvidu yang terlibat dalam pelaksanaan, serta melakukan pengawasan secara rutin saat proses penyusunan anggaran, sehingga penyusun anggaran mampu menyusun anggaran sesuai dengan pedoman yang telah disepakati bersama bagi keberlangsungan suatu organisasi sehingga meminimalisir terjadinya senjangan anggaran.

\section{REFERENSI}

Antari, N. K., \& Sukartha, I. M. (2017). Pengaruh Partisipasi Penyusunan Anggaran Dan Informasi Asimetri Pada Senjangan Anggaran Dengan Budaya Organisasi Sebagai Pemoderasi. E-Jurnal Akuntansi Universitas Udayana, 20(2), 929-958. https:/ / doi.org/10.24843/eja.2018.v22.i01.p19

Apriantini, N. K. erni, Adiputra, I. M. P., \& Sujana, E. (2014). Pengaruh Partisipasi Anggaran Terhadap Senjangan Anggaran dengan Penekanan Anggaran dan Komitmen Organisasi Sebagai Variabel Moderating (Studi Kasus Pada DinasDinas Pemerintah Kabupaten Buleleng). E-Journal S1 Akuntansi Universitas Pendidikan Ganesha, 2(1).

Ardanari, I. G. A. A., \& Putra, I. N. W. A. (2014). Pengaruh Partisipasi Penganggaran, Asimteri informasi, Self Estee dan Budget Emphasis Pada Budgetary Slack. E-Jurnal Akuntansi Universitas Udayana, 7(3), 700-715.

Ardianti, P. N. H., Suardikha, I. M. S., \& Saputra, I. D. G. D. (2015). Pengaruh Penganggaran Partisipatif Pada Budgetary Slack Dengan Asimetri Informasi, Self Esteem, Locus of Control Dan Kapasitas Individu Sebagai Variabel Moderasi (Studi Pada Skpd Kabupaten Jembrana, Bali). E-Jurnal Ekonomi Dan Bisnis Universitas Udayana, 4.05, 296-311.

Ardinasari, I. F. (2017). Kapasitas Individu, Budaya Organisasi, dan Asimetri Informasi pada Penyusunan Anggaran Partisipatif terhadap Budgetary Slack. 
Jurnal Profita, 1-19.

Ardiyani, F., \& Sukirno. (2017). Pengaruh Self Efficary, Reward and Punisment, dan Asimetri Informasi terhadap Budgetary Slack: Sudi Eksperimen pada Konteks Penganggaran Partisipatif. VI(1).

Asih, N. P. Y., Astika, I. B. P., \& Putri, I. G. A. . A. D. (2016). Pengaruh Partisipasi Penganggaran terhadap Budgetary Slack dengn Etika, Budaya Organisasi, Opportunistic Behaviour dan Ketidakpastian Lingkungan sebagai Pemoderasi. E-Jurnal Ekonomi Dan Bisnis Universitas Udayana, 5(12), 44154442.

Ayuni, N. M. K., \& Erawati, N. M. A. (2018). Pengaruh Asimetri Informasi Pada Senjangan Anggaran Dengan Kejelasan Sasaran Anggaran dan Komitmen Organisasi Sebagai Pemoderasi. E-Jurnal Akuntansi, 22(1), 492-520. https://doi.org/10.24843/eja.2018.v22.i01.p19

Dewi, N. luh P. S., \& Yasa, G. W. (2014). Analisis Pengaruh Anggaran Partisipatif pada Budgetary Slack dengan Empat Variabel Moderasi (Studi Kasus pada SKPD Kabupaten Badung, Bali). E-Jurnal Ekonomi Dan Bisnis Universitas Udayana, 3(1).

Dewi, N. P., \& Erawati, N. M. A. (2014). Pengaruh Partisipasi Penganggaran, Informasi Asimetri, Penekanan Anggaran dan Komitmen Organisasi pada Senjangan Anggaran. E-Jurnal Akuntansi Universitas Udayana, 9(2), 476-486.

Dianthi, I. A. G. P., \& Wirakusuma, M. G. (2017). Pengaruh Partisipasi Penganggaran, Asimetri Informasi, Budaya Organisasi Dan Komitmen Organisasi Pada Senjangan Anggaran. E-Jurnal Akuntansi Universitas Udayana ISSN : 2302-8556, 18(Vol.18.2), 874-901.

Fitra, I. (2017). Pengaruh Partisipasi Anggaran Kejelasan Sasaran Anggaran dan Komitmen Organisasi terhadap Budgetary Slack. Retrieved from http://www.albayan.ae

Hasanah, C. U., \& Suartana, I. W. (2014). Pengaruh Interaksi Motivasi dan Budaya Organisasi pada Hubungan Antara Partisipasi Penyusunan Anggaran dengan Senjangan Anggaran. E-Jurnal Akuntansi Universitas Udayana, 6(1), 4662.

Hikmahwati, Respat, N. W., Adriani, A., \& Mukhlisah, N. (2018). Pengaruh Partisipasi Anggaran dan Asimetri Informasi Terhadap Senjangan Anggaran dengan Komitmen Organisasi Sebagai Variabel Moderasi (Studi Empiris Politeknik Negeri Banjarmasin). 2(1), 2579-969X.

Huda, K., Sinarwati, N. K., \& Herawati, N. T. (2014). Pengaruh Partisipasi Anggaran Terhadap Senjangan Anggaran Dengan Budaya Organisasi Sebagai Variabel Pemoderasi Pada Pt Pos Indonesia ( Persero ) Singaraja. EJournal S1 Akuntansi Universitas Pendidikan Ganesha, 2(1).

Huseno, T. (2017). Pengaruh Partisipasi Anggaran, Komitmen Organisasi dan Ketidakpastian Lingkungan Terhadap Senjangan Anggaran Pemerintah Provinsi Sumatera Barat. Jurnal Teori Dan Riset Administrasi Publik, 1(1), 25793195. https:// doi.org/10.24036/j-trap.v1i1.12

Irfan, M., Santoso, B., \& Effendi, L. (2016). Pengaruh Partisipasi Anggaran terhadap Senjangan Anggaran dengan Asimetri Informasi, Penekanan Anggaran dan Komitmen Organisasional sebagai Variabel Pemoderasi. Jurnal Akuntansi

Dan

Investasi,

17(2),

158-175. 
https:// doi.org/10.18196/jai.2016.0052.158-175

Irfan, R. Z. (2017). Pengaruh Partisipasi Anggaran, Informasi Asimetri dan Budaya Organisasi terhadap Budgetary slack (Studi pada Satuan Kerja Perangkat Daerah Kota Surabaya). 2-4.

Koeswardhana, G., \& Saprudin. (2019). Pengaruh Partisipasi Penganggaran, Asimetri Informasi dan Budaya Organisasi Pada Senjangan Anggaran (Studi Kasus pada Hotels \& Resorts). Jurnal of Information System, Applied, Management, Accounting And Research, 3(2), 2598-8719. https:// doi.org/10.3975/cagsb.2019.031501

Kurniawan, Y. (2015). Pengaruh Asimetri Informasi, Kecukupan Anggaran, Komitmen Organisasi dan Ketidakpastian Lingkungan terhadap Hubungan Partisipasi Anggaran dengan Senjangan anggaran (Studi Empiris pada Satuan Kerja Perangkat Daerah Kota Dumai. 2(1), 1-15. https:/ / doi.org/10.1017/CBO9781107415324.004

Lestiana, L., \& Sari, M. M. R. (2017). Gaya Kepemimpinan Demokratis Memoderasi Pengaruh Asimetri Informasi dan Budaya Organisasi Pada Senjangan anggaran. E-Jurnal Akuntansi Universitas Udayana, 18(2), 847-873.

Luhur, I. B. S. C., \& Supadmi, N. L. (2019). Pengaruh Partisipasi Penganggaran, Informasi Asimetri, Komitmen Organisasi, dan Ketidakpastian Lingkunganpada Senjangan Anggaran. E-Jurnal Akuntansi Universitas Udayana, 26(2), 966-996.

Maharani, A. A. I., \& Ardiana, P. A. (2015). Pengaruh Partisipasi Penganggaran, Komitmen Organisasi, Dan Ketidakpastian Lingkungan Pada Senjangan Anggaran. E-Jurnal Akuntansi, 12(3), 770-785.

Meirina, E. (2018). Pengaruh Partisipasi Anggaran, Informasi Asimetris Dan Budget Emphasis Terhadap Slack Anggaran. JURNAL PUNDI, 2(3). https:// doi.org/10.31575/jp.v2i3.106

Mertayani, N. putu, \& Suardikha, I. M. (2017). Pengaruh Partisipasi Anggaran Pada Senjangan Anggaran Dengan Komitmen Organisasi Dan Gaya Kepemimpinan Sebagai Variabel Pemoderasi. E-Jurnal Akuntansi, 20(3), 19041932.

Mowday, R., Steers, R., \& Porter, L. (1979). The measurement of organizational commitment and professional commitment. Journal of Vocational Behavior, 14, 224-247. https:/ / doi.org/10.1080/00224545.1996.9714004

Mufarrihah. (2017). Pengaruh Partisipasi Penganggaran, Asimetri Informasi dan Budaya Organisasi pada Senjangan Anggaran (Studi Kasus pada Koperasi Di Kota Malang). 13-24.

Mukaromah, A., \& Suryandari, D. (2015). Pengaruh Partisipasi Anggaran, Asimetri Informasi, Komitmen Organisasi, Ambiguitas Peran Terhadap Budgetary Slack. Accounting Analysis Journal, 4(4), 1-8.

Nitiari, N. L. N., \& Yadnyana, K. (2014). Pengaruh Partisipasi Penganggaran, Komitmen Organisasi, Dan Ketidakpastian Lingkungan Pada Senjangan Anggaran. E-Jurnal Akuntansi Universitas Udayana, 9(3), 829-841.

Pamungkas, I. M. B. W., Adiputra, I. M. P., \& Sulindawati, N. L. G. E. (2014). Pengaruh Partisipasi Anggaran, Informasi Asimetri, Budaya Organisasi, Kompleksitas Tugas, Reputasi , Etika, ( Studi Pada Satuan Kerja Perangkat Daerah Jembrana). E-Journal S1 Akuntansi Universitas Pendidikan Ganesha, 2(1). 
Pello, E. (2014). Pengaruh Asimetri Informasi Dan Locus of Control Pada Hubungan Antara Penganggaran Partisipatif Dengan Senjangan Anggaran. E-Jurnal Akuntansi, 6(2), 287-305.

Prakasa, A. (2016). Pengaruh Perilaku Oportunistik, Etika Dan Komitmen Organisasi Legislatif Terhadap Senjangan Anggaran Pada Anggaran Pendapatan dan Belanja Daerah (APBD) Studi pada Anggota Dewan Perwakilan Rakyat Daerah (DPRD) Wilayah Provinsi Daerah Istimewa Yogyakarta. Retrieved from http://www.ghbook.ir/index.php

Prawira, I. G. N. H., \& Wirasedana, I. W. P. (2016). Budaya Organisasi sebagai Prediktor Partisipasi Penganggaran dan Implikasinya pada Senjangan Anggaran. E-Jurnal Akuntansi Universitas Udayana, 14(1), 144-171.

Saputra, K. D. ., \& Wijana Asmara Putra, I. . (2017). Pengaruh Partisipasi Anggaran dan Asimetri Informasi pada Senjangan Anggaran dengan Komitmen Organisasi Sebagai Variabel Pemoderasi. E-Jurnal Akuntansi Universitas Udayana, 19(1), 223-250.

Sari, N. L. E. Y., \& Putra, I. N. W. A. (2017). Kapasitas Individu, Self Esteem, Komitmen Organisasi, dan Penekanan Anggaran Memoderasi Partisipasi Penganggaran Pada Senjangan Anggaran. E-Jurnal Akuntansi Universitas Udayana, 20(2), 1189-1218.

Sujana, I. K. (2010). Pengaruh Partisipasi Penganggaran, Penekanan Anggaran, Komitmen Organisasi, Asimetri Informasi, Dan Ketidakpastian Lingkungan Terhadap Budgetary Slack Pada Hotel-Hotel Berbintang Di Kota Denpasar. Jurnal Ilmiah Akuntansi Dan Bisnis, 1-26.

Sukayana, G. A., \& Putri, I. G. A. . A. D. (2019). Tri hita karana culture and organizational commitments moderate: effect of participation on budgetary slack. International Research Journal of Management, IT and Social Sciences, 6(4), 180-188. https://doi.org/10.21744/irjmis.v6n4.676

Sulistyoningsih, S. (2018). Pengaruh Partisipasi Anggaran, Locus Of Control, Pemberian Reward dan Asimetri Informasi Terhadap Budgetary Slack (Studi Kasus Perusahaan Perhotelan Bintang 4 dan 5 di Surakarta).

Sundari, M., Nur, E., \& Anggraini, L. (2015). Pengaruh Asimetri Informasi, Penekanan Anggaran, Komitmen Organisasi Dan Locus of Control Terhadap Hubungan Partisipasi Anggaran Dengan Senjangan Anggaran (Studi Empiris Pada Satuan Kerja Perangkat Daerah Kota Sawahlunto). Jurnal Online Mahasiswa Fakultas Ekonomi Universitas Riau, 2(2), 1-15.

Wardhana, A. A. G., \& Gayatri, G. (2018). Pengaruh Partisipasi Anggaran, Asimetri Informasi, Ketidakpastian Lingkungan, Budaya Organisasi, dan Komitmen Organisasi pada Senjangan Anggaran. E-Jurnal Akuntansi, 25(3), 2098-2128. https://doi.org/10.24843/eja.2018.v25.i03.p18

Widodo, H. S. (2015). Pengaruh Komitmen Organisasional Terhadap Senjangan Anggaran Dengan Ideologi Etis Sebagai Variabel Pemoderasi. Kinerja, 19(1), 160-171. https:/ / doi.org/10.24002/ kinerja.v19i2.542

Widyasari, P. I., \& Ratnadi, N. M. D. (2018). Budaya Organisasi Berorientasi Hasil dan Komitmen Organisasi Sebagai Pemoderasi Pengaruh Partisipasi Penganggaran Pada Senjangan Anggaran. E-Jurnal Akuntansi, 25(3), 23522378. https:// doi.org/10.24843/eja.2018.v25.i03.p27 
Windiani, L. P., Sujana, E., \& Yasa, I. N. P. (2019). Pangaruh Partisipasi Penyusunan Anggaran, Asimetri Informasi, Komitmen Organisasi dan Budaya Organisasi Terhadap Potensi Timbulnya Budgetary Slack (Studi Kasus pada SKPD di Kabupaten Bangli). JIMAT(Jurnal Ilmiah Mahasiswa Akuntansi) Universitas Pendidikan Ganesha, 9(92), 2614-1930. https:// doi.org/10.1017/CBO9781107415324.004

Yasa, I. G. M., Diatmika, I. P. G., \& Prayudi, M. A. (2017). Pengaruh Partisipasi Anggaran, Penekanan Anggaran, Kejelasan Sasaran Anggaran, dan Self Esteem Terhadap Senjangan Anggaran Desa Di Kecamatan Kubutambahan. E-Journal S1 Akuntansi Universitas Pendidikan Ganesha, 8(2). 